\title{
The Information Content in Bank Currency Mismatches in Fixed Exchange Rate Regimes
}

\author{
Victoria Miller \\ Department of Economics, Université du Québec à Montréal, P.O. Box 8888, Station A, Montreal, Quebec, QC, Canada H3C 3P8 \\ Correspondence should be addressed to Victoria Miller, miller.victoria@uqam.ca \\ Received 11 May 2012; Accepted 20 June 2012 \\ Academic Editors: D. M. Hanink and M. T. Leung \\ Copyright () 2012 Victoria Miller. This is an open access article distributed under the Creative Commons Attribution License, \\ which permits unrestricted use, distribution, and reproduction in any medium, provided the original work is properly cited. \\ Banks tend to leave their currency exposures uncovered in fixed and "intermediate" exchange rate regimes. The paper asks why \\ this is the case. There are three possible explanations: First, hedges are costly and the currency peg is credible; Second, financial \\ markets are incomplete and so hedging instruments are unavailable; or third, hedges are costly and banks expect a bailout should \\ currency gyrations threaten their solvency. The paper demonstrates that the third argument is not time consistent and therefore \\ that uncovered currency exposures reflect currency peg credibility or financial incompleteness and not moral-hazard risk taking.
}

\section{Introduction}

Many Southeast Asian countries suffered currency and banking crises during the 1990s: Thailand, Indonesia, and Malaysia are just a few very notable examples of that period's twin crises. While their banking sectors were already fragile before the currency crises of 1997, their massive devaluations further weakened many banks that had failed to hedge their foreign exchange exposures. (Indeed, Burnside et al. [1], argue that banking fragilities and expected bailouts contributed to their currency crises).

The tendency to leave currency positions uncovered is not unique to Southeast Asia. As McKinnon and Pill [2] and Burnside et al. [3] have remarked, banks in countries with currency pegs tend to leave their currency exposures opened. (It is interesting that Arteta [4] demonstrates that an increase in exchange rate flexibility is associated with an increase of bank currency mismatches in transition and developing countries as those regimes encourage dollarization). The present paper asks why this is the case and investigates the information content in bank currency exposures in fixed exchange rate regimes.

There are several reasons why banks may fail to close their foreign exchange positions in fixed exchange rate regimes. first, countries with immature and incomplete financial markets also tend to be those that adopt currency pegs. Thus banks in such countries must absorb liquidity internationally in order to finance their domestic loan operations. (Eichengreen et al. [5] coined the phrase "original sin" to refer to this tendency to borrow abroad in foreign currencies). The incomplete nature of their financial markets means that hedging instruments simply are not available and results in currency mismatches.

However, even if markets are complete and hedging instruments are available, banks may still leave their positions uncovered: if hedges are costly and the currency peg is credible, then banks may not close their foreign exchange positions. A final reason that banks may not hedge their currency exposures in "intermediate" and fixed exchange rate regimes" is that they expect the central bank to use its, allbe-it limited, capacity to act as a lender-of-last resort and bail them out if currency gyrations become too great (see Eichengreen [6]). Indeed, Burnside et al. [1, 3] illustrate that the existence of government guarantees completely eliminates bank incentives to hedge away currency risk, and Corsetti et al. [7] and McKinnon and Pill [2] discuss how expected bailouts provided southeast Asian banks with incentives to over borrow in foreign. (Burnside et al. [8] show that when dollarized deposits are guaranteed (i.e., bank balance sheets are "shorting" the foreign currency), then selfvalidating currency crises may occur.) Thus, banks may leave their currency exposures uncovered in fixed exchange rate 
regimes if either markets are incomplete or complete but the peg is credible or a devaluation-contingent bailout is expected.

The present paper investigates the third argument and asks whether banks might expect devaluation-contingent bailouts in the absence of "guarantees." It will be shown that policy-makers will never have the incentive to follow devaluation with a bailout when both are expected. As bailouts will not be optimal (or "time consistent"), rational banks will never manage their portfolios expecting as much. That is, in currency pegs without guarantees, uncovered bank portfolios necessarily indicate currency peg credibility or financial immaturity (or incompleteness) and not moral hazard risk-taking.

The finding implies that in the absence of guarantees, banks will not manage their portfolios irresponsibly. An expost unexpected bailout will, therefore, not be a reward for moral-hazard risk-taking. It also follows that without such guarantees Southeast Asian banks may have managed their portfolios more responsibly so that their currency crises would not have had such devastating effects on their banks and economies.

The paper proceeds as follows: Section 2 presents the model to investigate whether banks may expect a devaluation-contingent bailout when deposits are not guaranteed. In the model with complete markets, banks choose their currency exposures before the central bank determines its exchange rate policy. As hedges are costly, banks will optimally not cover their currency exposures if either the peg is credible or devaluation-contingent bailouts are expected. The central bank then decides whether to "cheat" on its peg commitment and if so, whether or not to bailout banks. The conditions for currency peg credibility are first determined. For the peg to be credible, the central bank must not have the incentive to "cheat" on its peg regardless of whether or not such "cheating" is accommodated by a bailout. If the peg is credible, then banks will not hedge their currency exposures.

The conditions for the central bank to "cheat" on its peg are then analyzed. It will be shown that if the central bank is expected to "cheat" and then bailout banks, then the central bank will only have the incentive to "cheat" but not bailout banks. As a bank bailout will not be "time consistent," rational banks will never manage their portfolios with this in mind. That is, uncovered currency exposures in fixed exchange rate regimes (without deposit guarantees) never indicate expected bailouts but rather that markets are incomplete (i.e., hedges are unavailable) or complete and that the currency peg is credible. A final section concludes.

\section{Model}

The model of this small open economy with a currency peg is based on the following three equations:

$$
\begin{gathered}
i=i^{*}+\varepsilon^{e}+\rho \varepsilon, \\
y=\tilde{y}+\alpha\left(\varepsilon-\varepsilon^{e}\right)-\delta i, \\
L=(y-\grave{y})^{2}+B \varepsilon^{2}+C,
\end{gathered}
$$

where $B=\beta$ and $\rho=0$ if bailout occurs, $B=0$ and $\rho=p$ if no bailout occurs, $C=0$ if $\varepsilon=0$ and $C=c$ otherwise, $i, \varepsilon$ and $y$ are the domestic interest rate, the rate of depreciation, and output, respectively, and an asterisk indicates a foreign variable while a superscript " $e$ " denotes an expectation.

Equation (1) is the "ex-post" interest rate parity condition and merits some explanation. $\rho \varepsilon$ is a risk premium and measures how bank risk is affected by actual currency gyrations. If banks cover their currency positions or a bailout occurs, then bank portfolios will be unaffected by currency gyrations and so $\rho$ will be zero. If, however, banks fail to cover their positions (and are "shorting" the foreign currency) and bailouts do not occur, then devaluation will reduce bank solvency and increase domestic interest rates. As banks will choose not to cover their currency exposures only when the peg is credible or a devaluation-contingent bailout is expected, the ex-ante interest parity condition is simply $i=$ $i^{*}+\varepsilon^{e}$. However, as policy-makers decide whether or not to devalue (and if so whether or not to bailout) only after bank currency exposures or chosen, (1) is the relevant interest parity condition for policy-makers. (The government will be assumed to have a "devaluation-bias" so banks have no incentive to short the foreign currency in expectation of a capital gain).

Equation (2) is the output equation and indicates that output is equal to its trend level, $\tilde{y}$, and increases with surprise devaluations but is negatively affected by interest rate hikes. This illustrates that while surprise devaluations have an expansionary effect by stimulating export demand, they may also have a contractionary effect if banks are exposed and no bailout occurs.

Equation (3) is the government's loss function and shows that policy makers desire to get output as close to its target level, $y$ as possible. Equation (3) also includes a fixed cost, $C$, which will be positive if and only if the currency peg is violated and a term, $B \varepsilon^{2}$, which measures the cost of a bailout. Here the bailout cost is quadratic in the rate of depreciation and will be positive if and only if a bailout occurs and zero otherwise. (The result that bailouts are not time consistent also holds when bailout costs are linear in the rate of currency depreciation (i.e., equal to $2 B \varepsilon$ )). (Given bank currency exposures, devaluations will harm bank solvency while revaluations will improve it. Therefore, bailouts will only be plausible if a devaluation occurs). The term $B$ can be thought of as measuring the government's dislike for "unnecessary" or consequential inflation.

Substituting (1) and (2) into (3) and assuming that target output $\grave{y}$ is equal to its natural level, $\tilde{y}$, yield.

$$
L=\left[\alpha\left(\varepsilon-\varepsilon^{e}\right)-\delta\left(i^{*}+\varepsilon^{e}+\rho \varepsilon\right)\right]^{2}+B \varepsilon^{2}+C .
$$

Taking the derivative of the above expression with respect to $\varepsilon$ and setting the result equal to zero yield the general solution for the rate of devaluation that minimizes the loss function:

$$
\varepsilon=\frac{\left[\left[\delta i^{*}+(\alpha+\delta) \varepsilon^{e}\right](\alpha-\delta \rho)\right]}{\left[(\alpha-\delta \rho)^{2}+B\right]} .
$$

Assuming that hedges exist and are costly, banks will leave their FX positions opened if either exchange rates 
are rationally expected to remain fixed or if a bailout is expected to accompany devaluation. If it can be shown that policy-makers will never find it optimal to bailout banks after devaluation, then rational banks will not manage their portfolios expecting such a bailout. In other words, if devaluation-contingent bailouts are never optimal, then bank currency exposures can be taken to indicate that the peg is credible. We, therefore, first find the condition for the currency peg to be credible and then illustrate that a devaluation-contingent bailout is never optimal.

2.1. Currency Peg Credibility. To illustrate that the peg is credible, it must be demonstrated that given that $\varepsilon^{e}=0$, policy-makers have no incentive to devalue; regardless of whether or not any devaluation is accompanied by a bailout. Thus, given that $\varepsilon^{e}=0$, if policy-makers choose not to devalue, then setting $\varepsilon=\varepsilon^{e}=C=0$ in (4), their loss will equal $L_{\varepsilon=0}$

$$
L_{\varepsilon=0}=\left[\delta i^{*}\right]^{2} .
$$

If policy-makers opt for devaluation, then they must decide whether or not to accompany the devaluation with a bailout. If they opt for devaluation and no bailout, then $B$ will be zero and $\rho$ and $C$ will be strictly positive. Alternatively, a devaluation followed by bailout will result in a positive $B$ and zero valued $\rho$ and $C$. Thus, setting $B=0=\varepsilon^{e}$ and $\rho=p$, in (5), the optimal rate of devaluation given that no devaluation is expected and policy-makers do not bailout banks is ( $\alpha$ is assumed to be greater than $\delta p$ so that surprise devaluations yield more gains than losses and so the government has a devaluation bias)

$$
\varepsilon_{p} \mid\left(\varepsilon^{e}=0\right)=\frac{\delta i^{*}}{\alpha-\delta p} .
$$

The corresponding loss is $L_{p}$. ( $L_{p} \mid\left(\varepsilon^{e}=0\right)$ is found by setting $B=0=\varepsilon^{e}, \rho=p$, and $\varepsilon=\varepsilon_{p} \mid\left(\varepsilon^{e}=0\right)$ in (4).)

$$
L_{p} \mid\left(\varepsilon^{e}=0\right)=c .
$$

Alternatively, setting $B=\beta$ and $\varepsilon^{e}=\rho=0$ in (5) yields $\varepsilon_{\beta}$, the loss minimizing rate of devaluation for a policy of devaluing and bailing out banks when neither is expected.

$$
\varepsilon_{\beta} \mid\left(\varepsilon^{e}=0\right)=\frac{\delta i^{*} \alpha}{\left(\alpha^{2}+\beta\right)} .
$$

The loss corresponding to the strategy of "cheating" and "bailing out" banks is then $\left(L_{\beta} \mid\left(\varepsilon^{e}=0\right)\right.$ is found by setting $B=\beta, \varepsilon^{e}=\rho=0$, and $\varepsilon=\varepsilon_{\beta} \mid\left(\varepsilon^{e}=0\right)$ in (4).)

$$
L_{\beta} \mid\left(\varepsilon^{e}=0\right)=\frac{\left[\beta\left(\delta i^{*}\right)^{2}\right]}{\left(\beta+\alpha^{2}\right)}+c .
$$

For the currency peg to be credible, it must be the case that given that $\varepsilon^{e}=0$, policy-makers have no incentive to devalue; regardless of whether or not a devaluation is accompanied by a bailout. That is, currency peg credibility requires that $L_{\varepsilon=0}<L_{p} \mid\left(\varepsilon^{e}=0\right)$ and $L_{\varepsilon=0}<L_{\beta} \mid\left(\varepsilon^{e}=0\right)$. As $L_{p} \mid\left(\varepsilon^{e}=0\right)$ is trivially less than $L_{\beta} \mid\left(\varepsilon^{e}=0\right)$, policy-makers will never have an incentive to cheat and bailout banks when the peg is expected to endure. In other words, a sufficient condition for currency peg credibility is that $L_{\varepsilon=0}<L_{p}$ | $\left(\varepsilon^{e}=0\right)$ or $\left[\delta i^{*}\right]^{2}<c$. Thus, the larger the credibility cost of reneging on the peg and the smaller the losses of delivering the status-quo, the more likely the peg will be credible and banks will choose not to hedge their currency exposures.

\subsection{Expected Bailouts: Time Consistency and Rationality? If} $\left[\delta i^{*}\right]^{2}>c$, then the currency peg will not be credible and a devaluation will be expected. We now ask whether policymakers will ever have an incentive to accompany devaluation with a bailout. If it can be shown that a bailout is not time consistent, then uncovered currency positions (in complete markets) will only occur when the currency peg is infinitely credible and will not occur because of moral hazard risktaking.

Setting $\varepsilon=\varepsilon^{e}, B=\beta$, and $\rho=0$ in (5), the rationally expected rate of devaluation given that a bailout occurs is $\varepsilon_{\beta}{ }^{\mathrm{RE}}$

$$
\varepsilon_{\beta}{ }^{\mathrm{RE}}=\frac{\left(\delta i^{*} \alpha\right)}{\beta-\alpha \delta} .
$$

$\beta$ is assumed to be greater than $\alpha \delta$ so that devaluation is expected. (It is interesting that the expected rate of devaluation is smaller the larger the bailout cost is, $\beta$, and the smaller the gains from surprise devaluations, $\alpha$.) Then setting $\varepsilon=\varepsilon_{\beta}{ }^{\mathrm{RE}}$ in (4) and using the same values used to generate $\varepsilon_{\beta}{ }^{\mathrm{RE}}$ yield the corresponding loss for a rationally expected devaluation and bailout

$$
L_{\beta}{ }^{\mathrm{RE}}=\beta\left(\beta+\alpha^{2}\right)\left[\frac{\left(\delta i^{*}\right)}{\beta-\alpha \delta}\right]^{2}+c .
$$

If alternatively, devaluation and bailout are expected but policy makers opt only for devaluation, then setting $\varepsilon^{e}=$ $\varepsilon_{\beta}{ }^{\mathrm{RE}}, B=0$, and $\rho=p$ in (4) and (5), the optimal rate of devaluation is given by (As $\varepsilon_{p} \mid\left(\varepsilon^{e}=\varepsilon_{\beta}{ }^{\mathrm{RE}}\right)$ is assumed to be positive, it is greater than $\varepsilon_{\beta}{ }^{\mathrm{RE}}$.)

$$
\varepsilon_{p} \mid\left(\varepsilon^{e}=\varepsilon_{\beta}{ }^{\mathrm{RE}}\right)=\left(\delta i^{*}\right) / \frac{\left(\beta+\alpha^{2}\right)}{[(\alpha-\delta p)(\beta-\alpha \delta)]} .
$$

The corresponding loss is

$$
L_{p} \mid\left(\varepsilon^{e}=\varepsilon_{\beta}{ }^{\mathrm{RE}}\right)=c .
$$

As $L_{p} \mid\left(\varepsilon^{e}=\varepsilon_{\beta}{ }^{\mathrm{RE}}\right)$ is trivially less than $L_{\beta}{ }^{\mathrm{RE}}$, policymakers will never have an incentive to bailout banks when such is expected. As banks know that a bailout is not time consistent, they will not manage their risk with this in mind. In other words, uncovered bank portfolios in fixed exchange rate regimes with complete markets will only occur when the currency peg is credible and not because of moral-hazard risk taking. 
Finally, it should be noted that policy-makers will never have an incentive to not devalue when devaluation and bailout are expected. This can be seen by setting $\varepsilon^{e}=\varepsilon_{\beta}{ }^{\mathrm{RE}}$ and $\varepsilon=0$ in (4). The resulting loss for no devaluation when devaluation and bailout is expected is given by

$$
L_{\varepsilon=0} \mid\left(\varepsilon^{e}=\varepsilon_{\beta}{ }^{\mathrm{RE}}\right)=\left[\frac{\delta i^{*}\left(\beta+\alpha^{2}\right)}{\beta-\alpha \delta}\right]^{2} .
$$

Recall that the loss for devaluation only when devaluation and bailout are expected is $L_{p} \mid\left(\varepsilon^{e}=\varepsilon_{\beta}{ }^{R E}\right)=c$. Thus, for no devaluation to be preferred to devaluation, it must be the case that $L_{\varepsilon=0}\left|\left(\varepsilon^{e}=\varepsilon_{\beta}{ }^{\mathrm{RE}}\right)<L_{p}\right|\left(\varepsilon^{e}=\varepsilon_{\beta}{ }^{\mathrm{RE}}\right)$ or that $\left[\delta i^{*}\left(\beta+\alpha^{2}\right) /(\beta-\alpha \delta)\right]^{2}<c$. Looking at the conditions for currency peg credibility, it is clear that if the peg is not credible (i.e., $\left[\delta i^{*}\right]^{2}>c$ ), then the government will never have the incentive to not devalue.

\section{Discussion and Conclusion}

According to McKinnon and Pill [2] and Burnside et al. [3] banks in countries with currency pegs tend to leave their currency exposures open. There are three reasons why banks may fail to hedge their currency positions in fixed exchange rate regimes: First, financial markets are simply underdeveloped and banks are forced to absorb liquidity internationally to finance their domestic loan operations. Their financial immaturity results in a lack of hedging instruments. Second, hedges are costly and the exchange rate peg is credible; or third, as argued by Eichengreen [6] for "intermediate exchange rate regimes" and Burnside et al. [3], banks expect a bailout to accommodate any significant blow to solvency caused by currency gyrations.

The present paper asked whether bailouts are time consistent and whether a government would have an incentive to launch a devaluation-contingent bailout when not forced to do so. It was shown that when the central bank can renege on its peg and any bailout commitment, then it will never have the incentive to bailout banks. As a bailout is not time consistent, banks will never choose (i.e., when markets are complete) to "short" the foreign currency when the peg is not infinitely credible. That is, in fixed exchange rate regimes with complete financial markets and unguaranteed deposits, exposed bank portfolios necessarily indicate that the currency peg is credible and not moral hazard. It can, therefore, be argued that Southeast Asian banks would not have behaved similarly without their guarantees unless their pegs were credible or the immaturity of their financial markets forced them to do so.

It is interesting to note that many have argued that government guarantees should be avoided since they provoke excessive risk-taking and moral hazard behaviour on the part of banks. Burnside et al. [3] illustrate, for example, that the existence of guarantees completely eliminates bank incentives to hedge away risk. The present paper in no way refutes those arguments. Here we demonstrated that when there is a discretionary element to the government's currency and bailout decisions, guarantees are not time consistent and so banks will not manage their portfolios expecting devaluation-contingent bailouts. This suggests that in countries with fixed exchange rates, while ex-ante guarantees may not be optimal, unanticipated ex-post bailouts may actually be an effective policy tool to fill the void of financial incompleteness or limit the deleterious effects of unexpected and unavoidable devaluations. This may be especially true in developing countries where financial markets are immature and domestic finance is largely limited to banks so that policies that maintain their viability are crucial for economic well-being.

\section{References}

[1] C. Burnside, M. Eichenbaum, and S. Rebelo, "Prospective deficits and the Asian currency crisis," Journal of Political Economy, vol. 109, no. 6, pp. 1155-1197, 2001.

[2] R. I. McKinnon and H. Pill, "International overborrowing: a decomposition of credit and currency risks," World Development, vol. 26, no. 7, pp. 1267-1282, 1998.

[3] C. Burnside, M. Eichenbaum, and S. Rebelo, "Hedging and financial fragility in fixed exchange rate regimes," European Economic Review, vol. 45, no. 7, pp. 1151-1193, 2001.

[4] C. O. Arteta, "Exchange rate regimes and financial dollarization: does flexibility reduce currency mismatches in bank intermediation?" Topics in Macroeconomics, vol. 5, no. 1, article 10, p. 1226, 2005.

[5] B. Eichengreen, R. Hausmann, and P. Ugo, "The mystery of original sin," in Other People's Money: Debt Denomination and Financial Instability in Emerging Market Economics, B. Eichengreen and R. Hausmann, Eds., University of Chicago Press, Chicago, Ill, USA, 2005.

[6] B. Eichengreen, "Solving the currency conundrum," Economic Notes, vol. 29, no. 3, pp. 315-339, 2001.

[7] G. Corsetti, P. Pesenti, and N. Roubini, "Paper tigers? A model of the Asian crisis," European Economic Review, vol. 43, no. 7, pp. 1211-1236, 1999.

[8] C. Burnside, M. Eichenbaum, and S. Rebelo, "Government guarantees and self-fulfilling speculative attacks," Journal of Economic Theory, vol. 119, no. 1, pp. 31-63, 2004. 


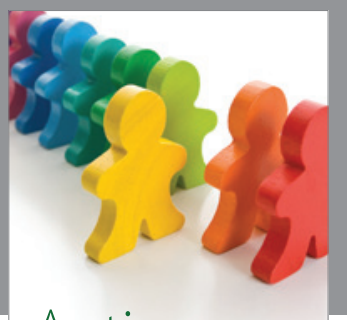

Autism

Research and Treatment
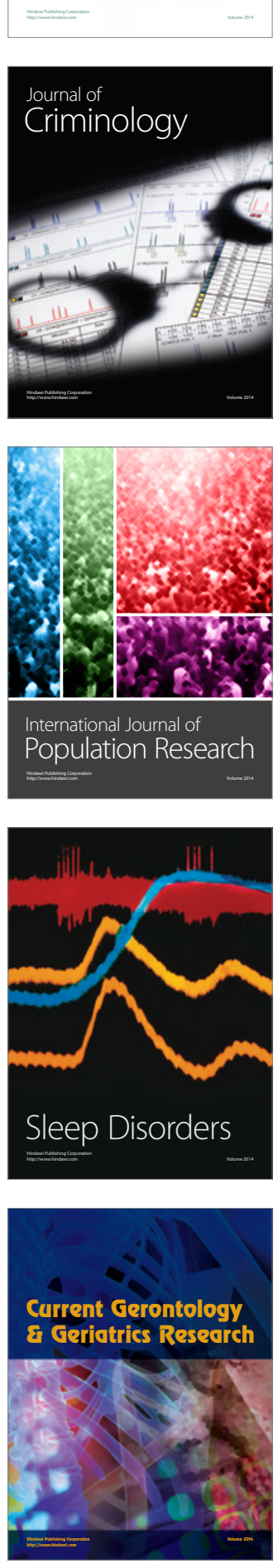
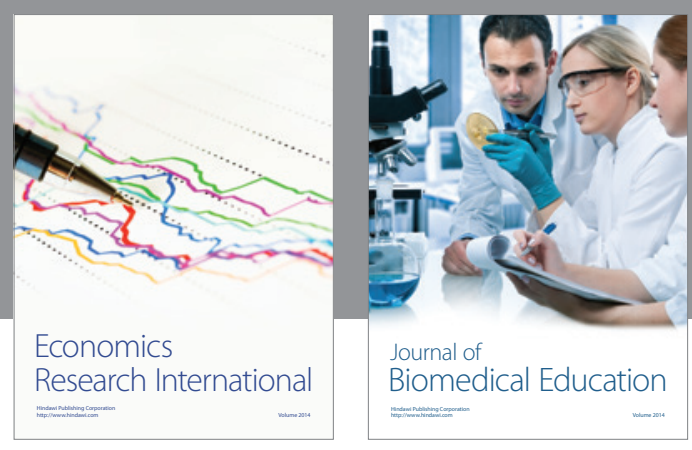

Journal of

Biomedical Education

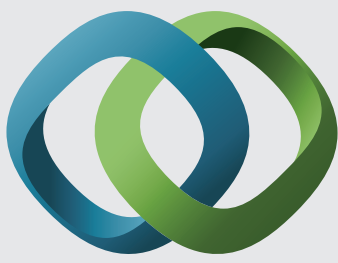

\section{Hindawi}

Submit your manuscripts at

http://www.hindawi.com
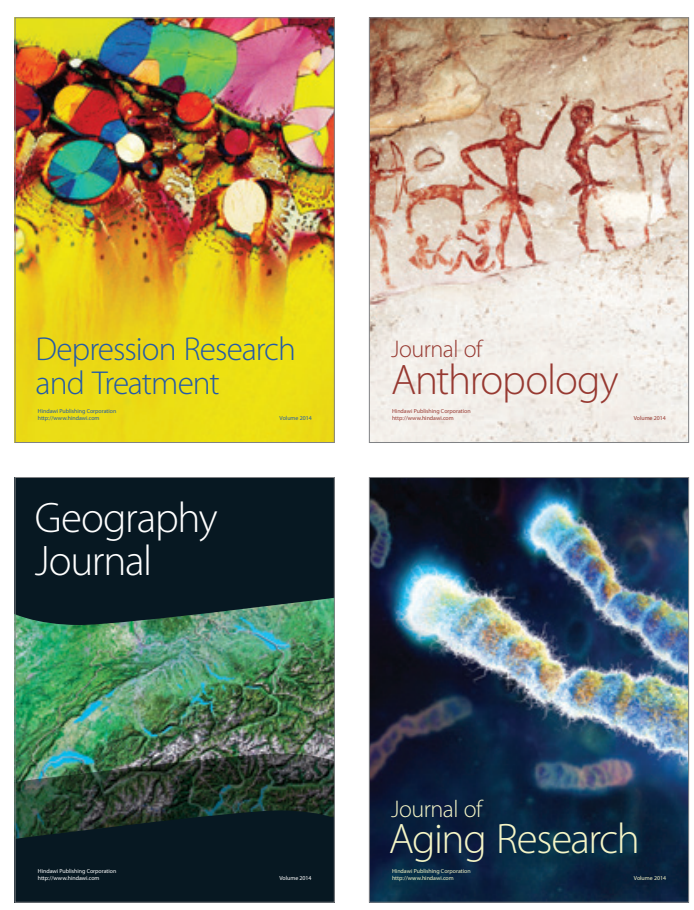

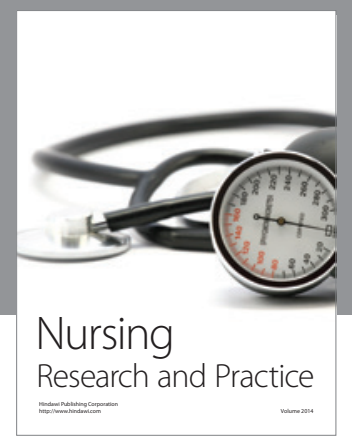

Nursing

Research and Practice

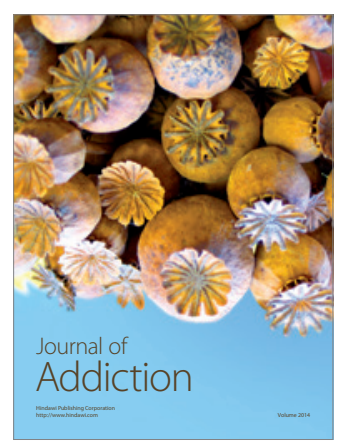

Child Development

Research

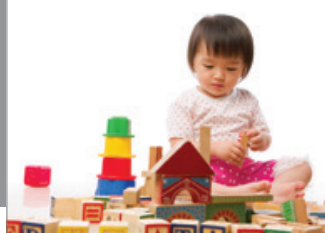

迥
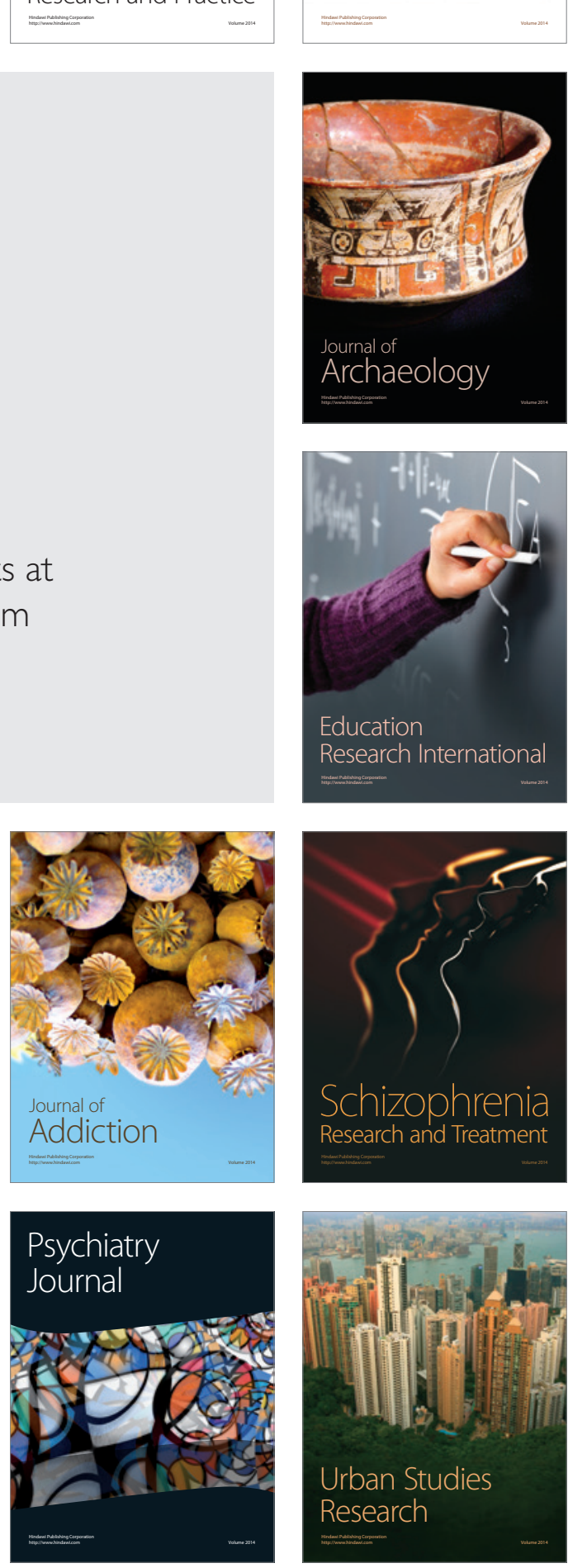